\title{
Diagenetic analysis of tetrapod from the Upper Triassic, Puesto Viejo Group, Argentina
}

\author{
* Elena Previtera' ${ }^{1}$,Adriana C. Mancusoํ, Marcelo S. de la Fuente ${ }^{2}$, Eloy S. Sánchez ${ }^{3}$ \\ ${ }^{I}$ Instituto Argentino de Nivología, Glaciología y Ciencias Ambientales (IANIGLA), CCT-CONICET-Mendoza, Avda. Ruiz Leal s/n \\ Parque Gral. San Martín, C.C. 330, (5500), Mendoza, Argentina. \\ eprevitera@mendoza-conicet.gob.ar; amancu@mendoza-conicet.gov.ar \\ 2 IANIGLA-CONICET-Museo de Historia Natural de San Rafael, Parque Mariano Moreno S/N, (5600) San Rafael, Argentina. \\ mdelafuente@mendoza-conicet.gob.ar \\ ${ }^{3}$ Laboratorio de Microscopía Electrónica y Microanálisis, Departamento de Física, Universidad Nacional de San Luis-CONICET, \\ Bloque 1 Planta Baja Ejército de los Andes 950, San Luis, Argentina. \\ esanchez@unsl.edu.ar \\ * Corresponding author: eprevitera@mendoza-conicet.gob.ar
}

\begin{abstract}
The Puesto Viejo Group crops out in the San Rafael Block, southwest Mendoza, Argentina. This group is an important unit for the knowledge theTriassic faunas. It is composed of basal Quebrada de los Fósiles Formation (QF) overlying by the Río Seco de la Quebrada Formation (RSQ). In this study, we report tetrapod remains from the RSQ Formation that includes, until now, exclusively therapsids. Non-mammalian therapsids predominated in terrestrial ecosystems during the Late Paleozoic and Early Mesozoic. Although cynodonts and dicynodonts have been studied from several perspectives, the relation between taxa and sedimentary context has been scarcely documented. This study is aimed to elucidate the diagenesis of tetrapods from the Puesto Viejo Group and its relation to depositional environment. Diagenetic features of therapsid bones from the RSQ Formation were analyzed through thin sections to interpret the degree of taphonomic alteration. Diagenetic processes inferred include substitution; fracturing; brittle deformation and different permineralization events. Combined analyses through scanning electron microscopy; energy-dispersive X-ray spectrometry (SEM-EDX); X-ray diffractometry (XRD) and petrographic studies reveals the substitution of hydroxyapatite by francolite. The presence of fluorine in some samples suggests a link between the elemental composition and depositional environments: floodplain and crevasse splay. Permineralization stages include infilling of vascular canals, trabeculae and fractures with iron oxides and iron carbonate minerals during the burial history. This contribution represents a relevant approach to elucidate the relation between diagenesis on tetrapods and their paleoenvironments, as exemplified in this case study from the Puesto Viejo Group during the Upper Triassic.
\end{abstract}

Keywords: Diagenesis, Therapsids, Upper Triassic, Puesto Viejo Group, Argentina.

RESUMEN. Análisis diagenético de tetrápodos del Triásico Superior, Grupo Puesto Viejo, Argentina. El Grupo Puesto Viejo aflora en el Bloque San Rafael, en el suroeste de Mendoza, Argentina. Este grupo constituye una importante unidad para el conocimiento de las faunas del Triásico y está compuesto en su base, por la Formación Quebrada de los Fósiles (QF), superpuesta por la Formación Río Seco de la Quebrada (RSQ). En este estudio, se reportan restos de tetrápodos de la Formación RSQ que incluye, hasta ahora, exclusivamente terápsidos. Los terápsidos no-mamiferoides predominaron en los ecosistemas terrestres durante el Paleozoico tardío y el Mesozoico temprano. A pesar de que cinodontes y dicinodontes han sido estudiados desde varias perspectivas, la relación entre los taxones y su contexto sedimentario está escasamente documentado. Este estudio tiene como objetivo dilucidar la diagénesis de los tetrápodos del grupo Puesto Viejo y su relación con el ambiente depositacional. Las características diagenéticas de los huesos de terápsidos de la Formación RSQ se analizaron a través de secciones delgadas para interpretar el grado de alteración tafonómica. Los procesos diagenéticos inferidos incluyen la sustitución, fracturación, deformación frágil y diferentes eventos de permineralización. El análisis combinado a través de microscopía electrónica de barrido, espectrometría de rayos X de energía dispersiva (SEM-EDX), difractometría de rayos X (DRX) y estudios petrográficos revelaron la sustitución de la hidroxiapatita por francolita. La presencia de flúor en algunas muestras sugiere la vinculación entre la composición elemental y los ambientes depositacionales: llanura de inundación y lóbulo de desbordamiento. Las etapas de permineralización incluyen el relleno de canales vasculares, trabéculas y fracturas con óxidos de hierro y carbonatos de hierro durante la historia de enterramiento. Esta contribución representa un enfoque relevante para dilucidar la relación entre la diagénesis de tetrápodos y sus paleoambientes, como lo demuestra este estudio de caso del Grupo Puesto Viejo durante el Triásico Superior. 


\section{Introduction}

The Triassic was a significant moment in the history of life with important changes in terrestrial ecosystems. Recently, an unexpected turn in the Triassic knowledge emerged from new reports about Argentinian sequences that modified their age and the biostratigraphic correlations of vertebrate assemblages (Ottone et al., 2014; Marsicano et al., 2015). One of these sequences is the Puesto Viejo Group, traditionally considered early Middle Triassic based on biostratigraphic correlations with the Karoo Basin (Bonaparte, 1969a; Abdala, 1996; Martinelli et al., 2009).

The Puesto Viejo Group crops out in the San Rafael Block, southwest Mendoza, Argentina. It is composed of mainly grayish basal Quebrada de los Fosiles Formation (QF) overlying by the reddish Río Seco de la Quebrada Formation (RSQ). The basal unit includes both plant remains (pleuromeians and sphenopsids) and vertebrates (scattered fish scales; dicynodont synapsids and remains of an archosauriform). In contrast, the RSQ beds report only tetrapod fauna, which includes kanemeyeriid dicynodonts (Domnanovich and Marsicano, 2012) and non-mammalian cynodonts (Bonaparte, 1966a, b, 1969a, b; Abdala, 1996; Martinelli et al., 2009).

Here, we report the tetrapod remains from the RSQ Formation that includes, until now, exclusively therapsids. Non-mammalian therapsids were important components of terrestrial ecosystems in Gondwana during the late Paleozoic and early Mesozoic (e.g., Langer et al., 2007; Abdala and Ribeiro, 2010; Mancuso et al., 2014). Among these, the anomodonts; gorgonopsians; therocephalians; dicynodonts and cynodonts have been studied in detail from different perspectives i.e., taxonomic, phylogenetic and functional morphology (e.g., Kemp, 1982; King, 1988; Crompton, 1995; Ray, 2000; Blob, 2001; Abdala and Ribeiro, 2010; Ruta et al., 2013). However, there has been little published about the relation between these vertebrates preservation and their sedimentary context (e.g., Smith, 1993; Rogers, 2001; Smith and Swart, 2002; Colombi et al., 2013).

The bone microstructure of well preserved fossil vertebrate in general and particularly in therapsids provides a host of information about ontogeny; skeletal age; lifestyle habits and growth patterns of the animal (e.g., Curry, 1999; Botha and Chinsamy, 2004; Ray and Chinsamy, 2004; Salgado et al.,
2005; Chinsamy and Abdala, 2008; García et al., 2010). Nevertheless, when skeletal elements are diagenetically altered during fossilization and their histological details are obliterated, the paleobiological explanation is limited. In this sense, our study deepens the information about tetrapods which was masked by diagenetic processes.

This work represents a holistic approach aimed to understand the link between preservation of tetrapods found in RSQ Formation and their sedimentary context. The range of diagenetic changes in bones has been estimated by means of mineral and chemical compositions. A series of taphonomic analyses: petrographic; EDX spectra and X-ray diffractometry were performed in thin sections of bones collected from specific environmental conditions: floodplain and crevasse splay.

\section{Geological Setting}

At the Permian-Triassic boundary, extensional basins were formed as an early manifestation of the supercontinent Pangaea breaking up (Uliana and Biddle, 1988; Ramos and Kay, 1991; Barredo et al., 2012). The San Rafael depocenter, located in Southern Mendoza, Argentina is one of these basins (Strelkov and Álvarez, 1984; Kokogian et al., 1993, 1999, 2001) (Fig. 1). During the Permian and Early Triassic, the San Rafael region manifested an active volcanism related to the Choiyoi extensional igneous province (Kay et al., 1989; Llambías et al., 1993; Llambías and Sato, 1995; Rocha-Campos et al., 2011), that continued during the deposition of the Triassic Puesto Viejo Group (Kleiman and Salvarredi, 2001; Kleiman and Japas, 2009). The basal Huárpica diastrophic phase (López Gamundi et al., 1989) separates the Cerro Carrizalito Formation (Permian) from the Puesto Viejo Group (Triassic). Syn-depositional extension occurred during the deposition of the Puesto Viejo Group, which includes sedimentary, volcaniclastic and volcanic rocks mostly light grey and reddish (Stipanicic et al., 2007). Triassic infill ended during the Upper Triassic (Ottone et al., 2014) and Puesto Viejo Group is unconformably overlain by the Miocene Aisol Formation (González Díaz, 1972).

The Puesto Viejo Group was interpreted as deposits from the middle-distal part of the alluvial fan, and low and high meandering fluvial systems characterized by conglomeratic and sandstone lens, 


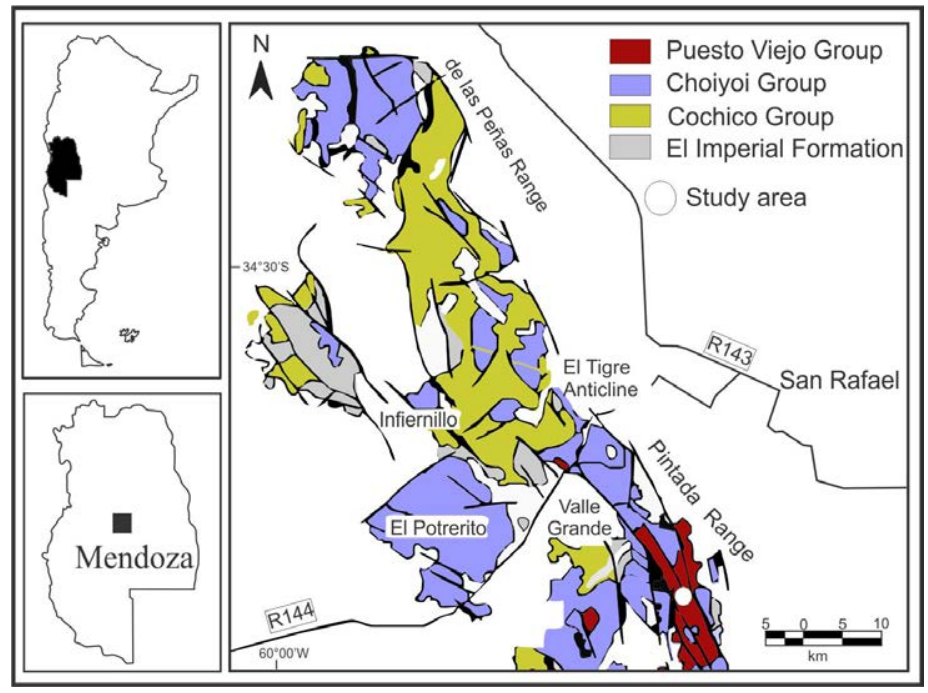

FIG. 1. Location map of the Puesto Viejo Group showing the Quebrada del Durazno area, Mendoza Province, Argentina.

crevasse channels and splays, and floodplains with paleosols (Spalletti, 1994). This group includes, from bottom to top, the grayish Quebrada de los Fósiles Formation (QF) and the mostly reddish Río Seco de la Quebrada Formation (RSQ) (Ottone et al., 2014).

The paleontological content of QF Formation includes palynomorphs; plants; invertebrates; and vertebrates (e.g., Ottone and García, 1991; Morel and Artabe, 1994; Bonaparte, 2002; Stipanicic et al., 2002; Sepúlveda et al., 2007; Gallego et al., 2009; Vaz-Tassi et al., 2013). Whereas the paleontological content of the RSQ Formation includes the mediumsized kanemeyeriid dicynodonts: Kanameyeria argentina and Vinceria sp. (Domnanovich and Marsicano, 2012) and the non-mammalian cynodonts: Pascualognathus polanskii, Cynognathus crateronotus and Diademodon tetragonus (Bonaparte, 1966a, b, 1969a, b; Abdala, 1996; Martinelli et al., 2009). This fauna is similar to subzones B and C of the Cynognathus Assemblage Zone (AZ), South Africa (Martinelli et al., 2009). Cynognathus crateronotus (Abdala, 1996) and Diademodon tetragonus, two of the most common cynodonts from the Cynognathus AZ of South Africa (Kitching, 1995) are present in the RSQ Formation, the Burgersdorp Formation of the Karoo Basin of South Africa, and the Omingonde Formation of Namibia. The new SHRIMP U-Pb age presented by Ottone et al., 2014 for the ignimbrite emplaced at the top of the QF Formation suggests that the tetrapod fauna of the RSQ Formation was developed during the Late Triassic (Early Carnian) thus $c a .10 \mathrm{Ma}$ later than the age attributed to the Cynognathus AZ of South Africa.

The RSQ Formation is characterized by reddish and whitish sediments. The volcanic rocks of the Puesto Viejo Group could have been originated by fissurale eruptions, although there is no evidence of volcanic cones in the study area (Ottone et al., 2014). Particularly in the Quebrada del Durazno area, the RSQ Formation is interpreted as channel, floodplain with crevasse channels, and crevasse splay facies. The high meandering fluvial system includes a coarse member with erosional bases, lentiform geometry dominated by normally graded conglomerates and coarse-grained sandstones with cross-stratification (Gt, SGt, St), (Spalletti, 1994; Ottone et al., 2014) constituting the channel fill (Fig. 2A). The fine member is mainly tabular with greater thickness than the coarse member dominated by overbank deposits in the floodplain (Fm, FTm, STm, Sm, see in Spalletti, 1994); and crevasse channel and splay deposits (St, Sl, Sh, see in Spalletti, 1994) (Fig. 2B).

Tetrapod remains were recovered from the fine member; mainly in the overbank and crevasse splay facies. The overbank is dominated by red massive mudstone and fine-grained sandstone showing greenish grey mottles and bands (Fig. 3A). The crevasse splay is characterized by red compact fine-to medium-grained sandstone with abundant invertebrate burrows at the top of the beds (Fig. 3B). Crevasse channels preserve 


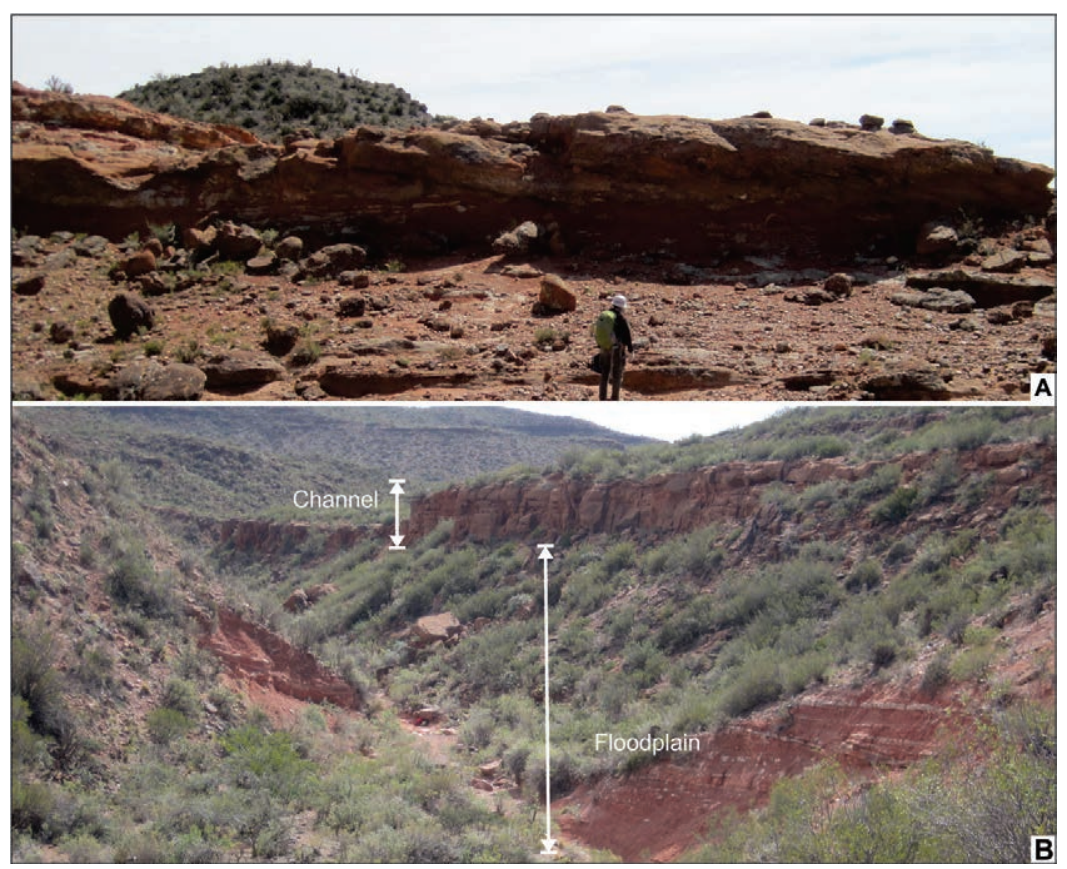

FIG. 2. Fluvial deposits of the Río Seco de la Quebrada Formation outcropping in the study area. A. Fluvial channels association; B. Floodplain facies association with crevasse channel and splay deposits.

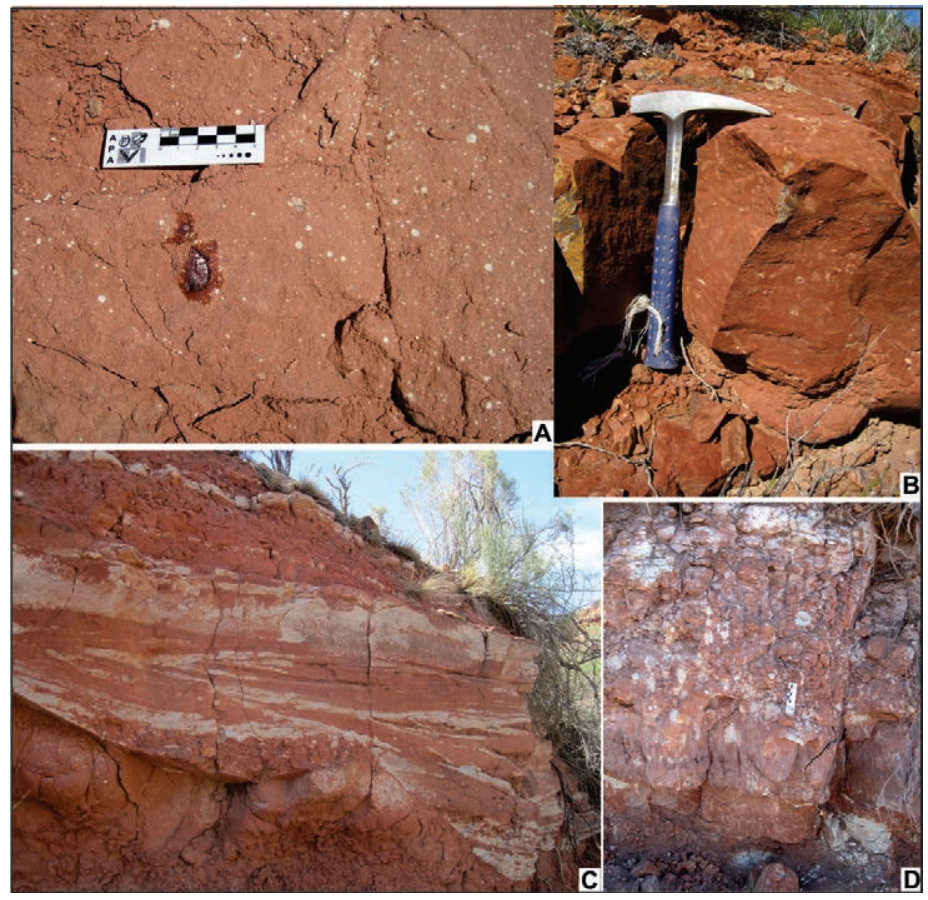

FIG. 3. Detail photographs of floodplain levels from Quebrada del Durazno site. A. Red fine-grained sandstone with light greenish grey mottled and banded beds containg fossil remains; B. Red compact fine-to medium-grained sandstone showing abundant bioturbation at the top; C. Crevasse channels with cross-bedded medium-to coarse-grained sandstone; D. Paleosols showing the abundant bioturbation levels and mottled and banded structures. 
some vertebrate remains. This facies is characterized by cross-stratification medium-to coarse-grained sandstone, with occasional conglomerate lags (Fig. 3C). Paleosols (Fig. 3D) are common in the sequence showing abundant root trace and discoloration.

The record of greenish grey mottled and band levels in the overbank suggests incipient paleosol formation (Freytet and Plaziat, 1982) whereas the root traces in the mudrock evidence the plant activity during a longer period of time in the paleosol formation. Therefore, during the paleosol and overbank deposits described here, we considered that the water table was subject to vertical fluctuations. Additionally, the abundant invertebrate burrows at the top of the crevasse splay evidenced period of time with enough water in the floodplain to enhance the bioturbation in these levels. The red and greenish grey mottled and band levels and the root trace in the fine member suggest a moderately well-drained overbank with water table fluctuation (Kraus and Hasiotis, 2006).

\section{Materials and Methods}

The studied material has been collected in the RSQ Formation at the Quebrada del Durazno site and preserved in the repository of the Museo de Historia Natural de San Rafael, Mendoza. The seven samples include ribs and appendicular elements of cynodonts (MHNSR.Pv.1159; MHNSR.Pv.1160; MHNSR.Pv.1162) and dicynodonts (MHNSR. Pv.1161; MHNSR.Pv.1163).

\subsection{Microscopic analysis}

Thin sections of fossil bones were processed following the techniques outlined by Chinsamy and Raath (1992) and observed under plane and cross-polarized light with a petrographic microscope (BX 51-P Olympus). Histological terminology and definitions generally follow those of Reid (1996) and Chinsamy-Turan (2005). This paper takes the criteria used by various authors about diagenetic processes (Schmidt and McDonald, 1979; Burley et al., 1985; Scasso and Limarino, 1997).

\subsection{EDX spectra}

Elemental compositions of the carbon-coated samples were obtained using a LEO $1450 \mathrm{VP}$ scanning electron microscope equipped with an
EDAX Genesis 2000 energy-dispersive spectrometer (EDS) with a polypropylene ultrathin window $\mathrm{Si}(\mathrm{Li})$ detector. Spectra were analyzed using the software EDAX Genesis 2000. Working conditions included an acquisition live time of 200 seconds, nominal incident beam energy $\mathrm{E}_{\mathrm{o}}=15 \mathrm{keV}$, and $15 \mathrm{~mm}$ working distance. The average weight of major elements of the samples -O, F, Na, Mg, Al, Si, P, K and Ca, Mn and $\mathrm{Fe}$ - was determined at each point-scans. These elements were selected with the purpose of including major cations for rock- matrix minerals (e.g., silicate, carbonate), major pore fillers (e.g., iron, calcite) and species representing the original bone (e.g., carbonate, phosphate). The results of semi-quantitative data reported statistical errors -not shown- for these concentrations. Elements with percentages greater than $10 \%$ present an error of $4 \%$; other elements with percentages ranging between $10 \%-1 \%$, the statistical error is of the $15 \%$ and finally, elements with lower percentages than $1 \%$ present an error of the $20 \%$.

\subsection{X-ray diffractometry (XRD)}

Qualitative analysis of crystalline solids were performed with a RIGAKUD- MAX IIIC diffractometer using copper lamp operated by nickel filter at $30 \mathrm{kV}$, $20 \mathrm{~mA}$, scanning speed of $1.5 \% \mathrm{~min}$., pitch reading of $0.05^{\circ}$ continuous. The samples were ground until granulometries less than 200 mesh in a rings mill (Fritsch Analisette). Analysis by X-ray diffractometry of specimens showed the presence of crystalline structures of the following chemical elements: $\mathrm{O}$, F, Na, Si, Al, P, K, Ca, Mg, Mn and Fe previously determined by EDX.

Institutional Abbreviations: MHNSR.Pv.: Museo de Historia Natural de San Rafael, Mendoza, Argentina, Paleontología de Vertebrados.

Histological and Diagenetic Abbreviation: Figs. 4, 6. FL: fibrolamellar bone; LB: lamellar bone; LAGs: lines of arrested growth; P: perimedullary region; Mc: medullary cavity; Cs: cancellous spaces; T: trabeculae; Ap: apatite; Fc: ferroan calcite; Fe: iron; Mn: manganese; Cal: calcite; Sd: siderite; S: silt; FAp: fluorapatite; Mnt: montmorillonite; OHAp: hydroxyapatite; Phyll: phyllosilicate; Qtz: quartz.

\section{Pre-burial and Post-burial Modification}

The bones recovered in a floodplain facies (MHNSR.Pv.1159; MHNSR.Pv.1160 and MHNSR. 
Pv.1163) exhibit features assigned to pre-fossilization weathering. Both, appendicular bones and ribs, show a high grade of pre-burial cracking (stages 1-3 of Behrensmeyer, 1978). Their upper surface displays longitudinal fractures parallel to bone fibers. These fractures were produced by pre-burial subaerial exposure and cemented during the post-burial stages. Outermost concentric thin layers of bone show flaking usually associated with splintered cracks. In some sectors, deeper and more extensive flaking follows, until most of the outermost bone is gone. Thus, the inner cancellous bone of the epiphyses is exposed. Some weathered bones were more vulnerable to abrasion and breakage. In such abrasion, a significant rounding of broken edges of bones was produced.

In contrast, the bones found in a crevasse splay (MHNSR.Pv.1161 and MHNSR.Pv.1162) show little evidence of pre-fossilization weathering as a result of prolonged subaerial exposure, predation or trampling. Various bones exhibit perpendicular fractures to the bone long axis occurred during fossil-diagenetic stages (Fernández López and Fernández Jalvo, 2002). Some bones recovered on the soil surface indicate post-fossilization weathering evidenced by the presence of non-cemented fractures reflecting exhumation events.

\section{Bone microstructure and diagenesis}

This section includes a detailed description of the bone microstructure and diagenetic sequence of each specimen to indicate their preservation state (Tables 1 and 2). Overgrowth patterns of the minerals indicate relative time of formation.

TABLE 1. DIAGENETIC FEATURES OF THE CYNODONT AND DICYNODONT TAXA EXAMINED.

\begin{tabular}{|c|c|c|c|c|}
\hline Specimen & Taxa & Bones & Facies & Diagenetic processes \\
\hline MHNSR-PV 1159 & Cynodont & Rib & Floodplain & $\begin{array}{l}\text { Permineralization stages include: (1) iron oxides cementation } \\
\text { in osteons and medullary tissue; (2) siderite encrustation in } \\
\text { vascular canals; (3) calcite cementation in vascular canals. } \\
\text { Scarce brittle deformation. }\end{array}$ \\
\hline
\end{tabular}

MHNSR-PV 1160 Cynodont Rib Floodplain Diagenetic processes: (1) iron oxides cementation in vascular canals, medullary tissue and longitudinal fractures; (2) calcite cementation in vascular canals and fractures; (3) an infiltration of iron carbonates on the cortical wall. Fracturation and brittle deformation.

\begin{tabular}{|c|c|c|c|c|}
\hline MHNSR-PV 1161 & Dicynodont & $\begin{array}{l}\text { Bone } \\
\text { Fragment }\end{array}$ & Crevasse Splay & $\begin{array}{l}\text { Permineralization stages include: (1) iron oxides cementation } \\
\text { in vascular canals, medullary cavity and radial fractures; (2) } \\
\text { calcite precipitation in some vascular canals. }\end{array}$ \\
\hline \multirow[t]{2}{*}{ MHNSR-PV 1162} & Cynodont & Rib & Crevasse Splay & $\begin{array}{l}\text { Cortical region: iron oxides coating in osteons, vascular } \\
\text { canals and radial Fractures. Perimedullary and medullary } \\
\text { areas: vascular canals, fractures and cancellous spaces infilled } \\
\text { in two permineralization events: (1) iron oxides coating; (2) } \\
\text { calcite cementation. }\end{array}$ \\
\hline & & $\begin{array}{l}\text { Appendicular } \\
\text { Bone }\end{array}$ & & $\begin{array}{l}\text { Diagenetic processes: (1) iron oxides coating in vascular } \\
\text { canals and fractures (2) drusy calcite cementation in vascular } \\
\text { canals and cancellous spaces; ( } 3 \text { ) an infiltration of iron oxides } \\
\text { imposed onto the medullary tissue. Fracturation and brittle } \\
\text { deformation. }\end{array}$ \\
\hline \multirow[t]{2}{*}{ MHNSR-PV 1163} & Dicynodont & Rib & Floodplain & $\begin{array}{l}\text { In both remains it is observed similar diagenetic features. } \\
\text { Cortical region: (1) rim of iron oxides in osteons; }(2) \text { growth } \\
\text { of calcite in vascular canals; (3) infiltration of iron oxides in } \\
\text { longitudinal fractures of the cortical wall. }\end{array}$ \\
\hline & & $\begin{array}{l}\text { Appendicular } \\
\text { Bone }\end{array}$ & & $\begin{array}{l}\text { Medullary region: (1) a rim of carbonate-cemented silty } \\
\text { sediment; (2) growth of fibrous calcite in vascular canals; } \\
\text { (3) blocky calcite infilling trabeculae and cancellous spaces }\end{array}$ \\
\hline
\end{tabular}


TABLE 2. SEMI-QUANTITATIVE CONCENTRATIONS OF MAJOR ELEMENTS GIVEN AS WEIGHT \% (WT\%). THE HIGHLIGHTED ITEMS ARE PLOTTED IN FIGURE 5.

\begin{tabular}{|c|c|c|c|c|c|c|c|c|c|c|c|}
\hline Specimen/elements & $\mathbf{O}$ & $\mathbf{F}$ & $\mathrm{Na}$ & $\mathrm{Si}$ & Al & $\mathbf{P}$ & $\mathbf{K}$ & $\mathbf{C a}$ & Mg & Mn & $\mathrm{Fe}$ \\
\hline & 48.53 & 5.75 & 0.99 & 0 & 0.16 & 15.03 & 0.14 & 29.21 & 0 & 0 & 0 \\
\hline MHNSR-PV1159 & 46.99 & 5.42 & 0.77 & 1.62 & 0.48 & 14.88 & 0 & 29.84 & 0 & 0 & 0 \\
\hline Cynodont & 47.57 & 4.31 & 1.06 & 6.27 & 1.67 & 10.47 & 0 & 24.62 & 0.73 & 0 & 3.30 \\
\hline \multirow[t]{4}{*}{ Floodplain facies } & 54.04 & 1.45 & 0.35 & 2.91 & 0.89 & 1.73 & 0.09 & 35.05 & 0.25 & 0 & 3.25 \\
\hline & 45.60 & 2.38 & 0.70 & 19.35 & 6.54 & 5.55 & 0.79 & 15.79 & 0.79 & 0 & 2.51 \\
\hline & 51.17 & 1.24 & 2.09 & 8.53 & 3.23 & 2.39 & 0.49 & 28.58 & 0 & 0 & 1.11 \\
\hline & 1.69 & 0 & 0 & 18.67 & 0 & 0 & 0 & 8.25 & 0 & 42.36 & 29.03 \\
\hline MHNSR-PV1161 & 26.86 & 0 & 0.78 & 40.25 & 3.13 & 1.36 & 5.66 & 4.41 & 0.23 & 6.40 & 10.31 \\
\hline Dicynodont & 24.23 & 0 & 0.14 & 11.62 & 1.34 & 1.08 & 0.64 & 2.82 & 0.21 & 53.86 & 3.56 \\
\hline PV1159Crevasse splay & 34.53 & 0 & 0.66 & 43.38 & 3.80 & 1.58 & 1.77 & 3.60 & 0.68 & 1.74 & 8.26 \\
\hline \multirow[t]{3}{*}{ facies } & 19.14 & 0 & 0 & 2.15 & 0.59 & 7.74 & 0 & 45.95 & 0 & 16.04 & 8.40 \\
\hline & 49.08 & 0 & 0 & 1.08 & 0.32 & 0.96 & 0 & 44.80 & 0 & 3.76 & 0 \\
\hline & 42.78 & 0 & 0.52 & 2.40 & 0.72 & 13.78 & 0 & 29.29 & 0 & 0 & 10.52 \\
\hline MHNSR-PV1162 & 38.41 & 0 & 0.57 & 2.07 & 0.66 & 15.52 & 0.67 & 34.52 & 0.15 & 0 & 7.43 \\
\hline Cynodont & 30.07 & 0 & 0.45 & 13.37 & 3.31 & 1.71 & 1.71 & 3.26 & 0.54 & 0.85 & 44.26 \\
\hline Crevasse splay & 40.18 & 0 & 7.40 & 31.61 & 11.49 & 1.01 & 0.42 & 2.20 & 0 & 1.66 & 4.04 \\
\hline \multirow[t]{3}{*}{ facies } & 42.06 & 0 & 0.95 & 2.67 & 1.00 & 12.77 & 0 & 27.53 & 0 & 0 & 13.03 \\
\hline & 46.97 & 0 & 0.65 & 1.52 & 0.50 & 15.57 & 0 & 33.57 & 0 & 0 & 1.21 \\
\hline & 34.26 & 3.06 & 0.39 & 1.13 & 0.85 & 12.09 & 0 & 25.67 & 0.33 & 5.99 & 2.87 \\
\hline MHNSR-PV1163 & 41.89 & 1.71 & 0.26 & 0.95 & 0.36 & 11.23 & 0 & 31.40 & 0 & 2.21 & 3.49 \\
\hline Dicynodont & 36.10 & 3.35 & 0.45 & 1.31 & 0.31 & 17.03 & 0 & 37.62 & 0 & 1.64 & 2.01 \\
\hline \multirow[t]{3}{*}{ Floodplain facies } & 36.01 & 4.20 & 0 & 0.83 & 10.22 & 3.34 & 0 & 7.06 & 2.01 & 33.21 & 2.84 \\
\hline & 36.06 & 3.73 & 0.47 & 1.51 & 1.42 & 13.08 & 0 & 27.34 & 0 & 10.23 & 4.92 \\
\hline & 34.35 & 2.74 & 0.35 & 0.95 & 0 & 17.98 & 0 & 41.67 & 0 & 1.55 & 0 \\
\hline
\end{tabular}

\subsection{MHNSR.Pv.1159, Cynodont indet.}

The sample studied corresponds to a rib found in a floodplain facies. Thin sections display a wellpreserved bone microstructure containing a small medullary cavity surrounded by a thick cortex. The cortex of the rib comprises lamellar and fibrolamellar bone tissues showing simple canals and primary osteons permineralized by iron oxides (e.g., hematite) and calcite $\left(\mathrm{CaCO}_{3}\right)$ (Fig. 4A, Table 1). Perimedullary region displays an extensive secondary remodeling with a development of secondary osteons and resorption cavities. In this region, vascular canals show scarce brittle deformation and are infilled by iron oxides, siderite $\left(\mathrm{Fe}_{2} \mathrm{CO}_{3}\right)$ and calcite (Fig. 4B). Medullary cavity contains large cancellous spaces and bony trabeculae mainly occupied by iron oxides with scarce calcite (Fig. 4C). Permineralization stages include: (1) an initial iron oxides cementation in osteons and medullary tissue, then (2) a siderite encrustation in bone vascular canals and followed by (3) calcite cementation in the centre of vascular canals.

The diagenetic processes affecting the bones were permineralization -mentioned before- and the 


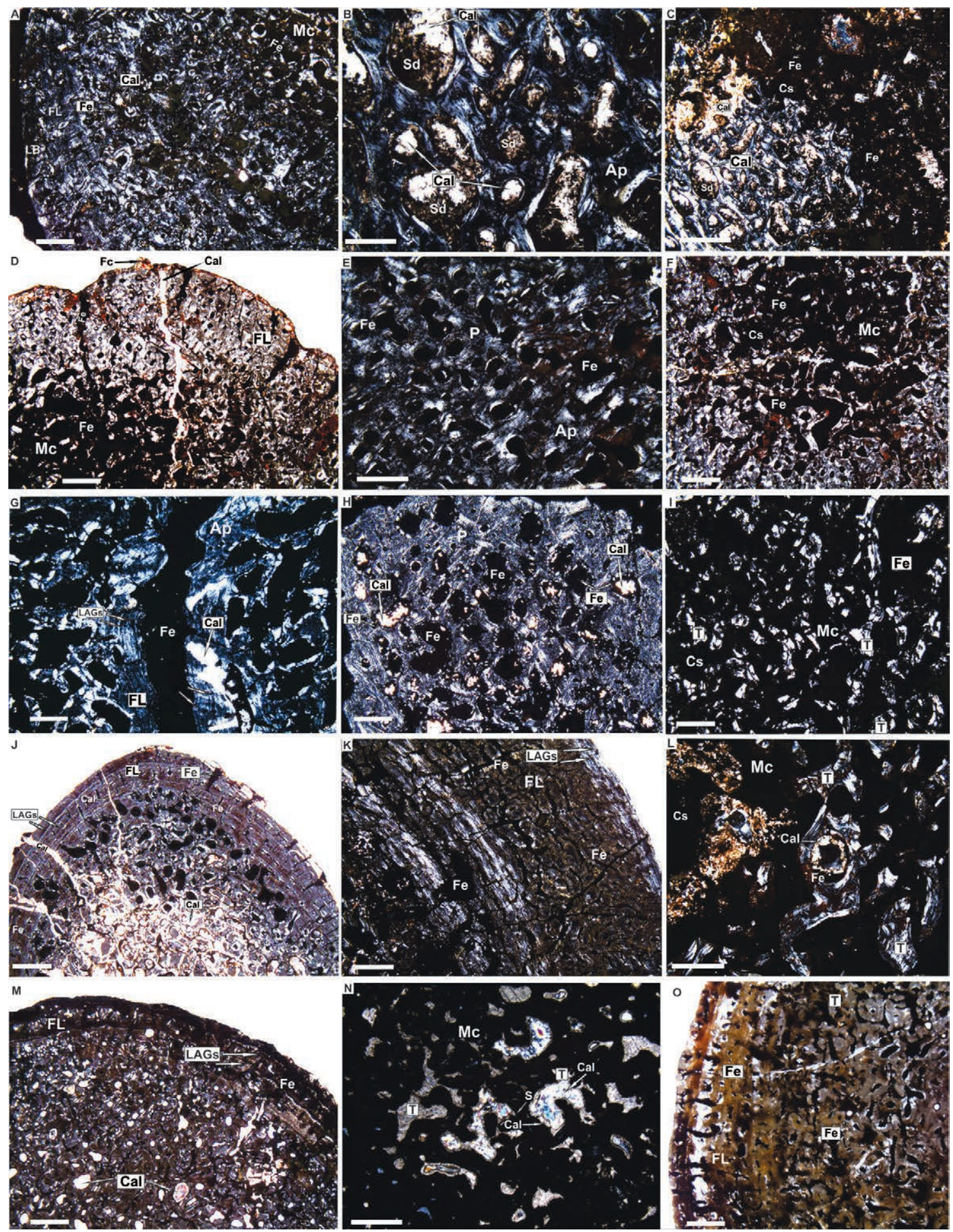

FIG. 4. Transverse sections of cynodont and dicynodont bones. A-C. Cynodont rib MHNSR.Pv.1159; D-F. Cynodont rib MHNSR. Pv.1160; G-I. Dicynodont bone fragment MHNSR.Pv.1161; J. Cynodont rib MHNSR.Pv.1162; K-L. Cynodont appendicular bone MHNSR.Pv.1162; M-N. Dicynodont rib MHNSR.Pv.1163; O. Dicynodont long bone MHNSR.Pv.1163. Photomicrographs in cross-polarized light. Scale bar equals $1 \mathrm{~mm}$. See text for further explanation. 
substitution of hydroxyapatite $\left[\mathrm{Ca}_{5}\left(\mathrm{PO}_{4}\right)_{33}(\mathrm{OH})\right]$ by francolite $\left[\mathrm{Ca}_{5}\left(\mathrm{PO}_{4}, \mathrm{CO}_{3}\right)_{3}(\mathrm{~F})\right]$, a carbonaterich type of fluorapatite. EDX spectra indicate the presence of fluorine, as shown by the peak at $0.67 \mathrm{keV}$ (Fig. 5). X-ray diffraction shows the presence of several crystalline phases based on the chemical composition: $\mathrm{O}, \mathrm{F}, \mathrm{Na}, \mathrm{Si}, \mathrm{Al}, \mathrm{P}, \mathrm{Ca}, \mathrm{Mg}$ and $\mathrm{Fe}$ (Table 2). The presence of fluorapatite appears as the main signal in the diffractogram (Fig. 6). Other minority phases that could be attributed to quartz and calcite are observed in a very low proportion. These analyses display recrystallization to francolite, which is a typical mineral replacement of fossilized bone (Elorza et al., 1999; Rogers et al., 2010).

\subsection{MHNSR.Pv.1160, Cynodont indet.}

The sample analyzed is from a rib of another cynodont found in the floodplain facies. Transverse sections show a compact cortex surrounding a central cancellous region. The external cortex is formed by fibrolamellar bone with primary osteons and vascular canals filled by iron oxides and, to a lesser extent, calcite (Fig. 4D, Table 1). Toward the inner cortex, the perimedullary region contains abundant secondary osteons filled with iron oxides (Fig. 4E). The medullary cavity shows endosteal trabeculae and cancellous spaces occupied by iron oxides (Fig. 4F). Lithostatic pressure and the consequent deformation of bone tissue caused complex fracture systems cutting the vascular canals and thus modifying the original structure. Diagenetic processes include: (1) an initial iron oxides cementation within vascular canals of the perimedullary region, medullary tissue, and longitudinal fractures (Fig. 4D-F) then, (2) calcite cementation infills some vascular canals and fractures (Fig. 4D) and finally (3) an infiltration of iron carbonate minerals covering directly bone tissue on the cortical wall (Fig. 4D). The presence of calcite and iron enrichment (possibly corresponding to ferroan calcite) indicates local reducing conditions below the water table during precipitation (Previtera et al., 2013).

This specimen shows similar diagenetic processes to those described in rib sample MHNSR.Pv.1159 (Table 1). EDX spectra indicate the presence of fluorine as shown by the peak at $0.67 \mathrm{keV}$ (see Previtera et al., 2013: Fig. 3.2). XRD display the preponderance of fluorapatite and a negligible presence of quartz (Fig. 6), thus proving recrystallization to francolite.

\subsection{MHNSR.Pv.1161, Dicynodont indet.}

This sample consists of a bone fragment of dicynodont recovered in a crevasse splay facies. Transverse sections display a parallel-fibred bone forming the subperiosteal surface surrounding a central medullary cavity. The inner cortex contains fibrolamellar bone with primary osteons interrupted by lines of arrested growth (LAGs) (Fig. 4G). The perimedullary region contains abundant secondary osteons with radial fractures cutting and distorting the vascular canals (Fig. 4H). Medullary cavity shows an intrincate network of trabeculae and cancellous spaces forming islets (Fig. 4I). The primary osteons and vascular canals are mainly filled by iron oxides and in less proportion by calcite (Fig. 4G-I, Table 1). Permineralization stages include: (1) an initial iron oxides cementation in vascular canals, medullary tissue, and radial fractures (Fig. 4G-I) and followed by (2) a calcite precipitation in the center of some vascular canals (Fig. 4H). EDX spectra indicates the presence of $\mathrm{O}, \mathrm{Na}, \mathrm{Mg}, \mathrm{Al}, \mathrm{Si}, \mathrm{P}, \mathrm{K}, \mathrm{Ca}, \mathrm{Mn}$ and Fe (Fig. 5, Table 2). XRD show a slight signal of phosphates zone, which can be attributed to hydroxyapatite, since fluoride is not reported in the analysis. It can be observed three intense peaks possibly attributed to a phyllosilicate. These results were not conclusive, therefore, this sample was not considered for the XRD analysis.

\subsection{MHNSR.Pv.1162, Cynodont indet.}

The samples consist of a rib and an appendicular fragment of cynodont found in a crevasse splay facies. The rib is similar to the appendicular element in terms of the cortical tissue type, endosteal bone deposition, and secondary remodeling. In contrast, they show differences in their diagenetic features.

The transverse section of the rib shows a cortex zonal containing wide zones of fibrolamellar bone interrupted by some LAGs (Fig. 4J). This cortical region displays different diagenetic pathways (Table 1). In the external cortex, longitudinally oriented primary osteons and radial fractures are mainly filled by iron oxides (Fig. 4J). However, some longitudinal fractures show a thin coating of iron oxides and fibrous calcite cementation (Fig. 4J). Towards the inner cortex, secondary osteons -reflecting Haversian remodelingcontain central vascular canals and radial fractures filled by iron oxides (Fig. 4J). Perimedullary and 


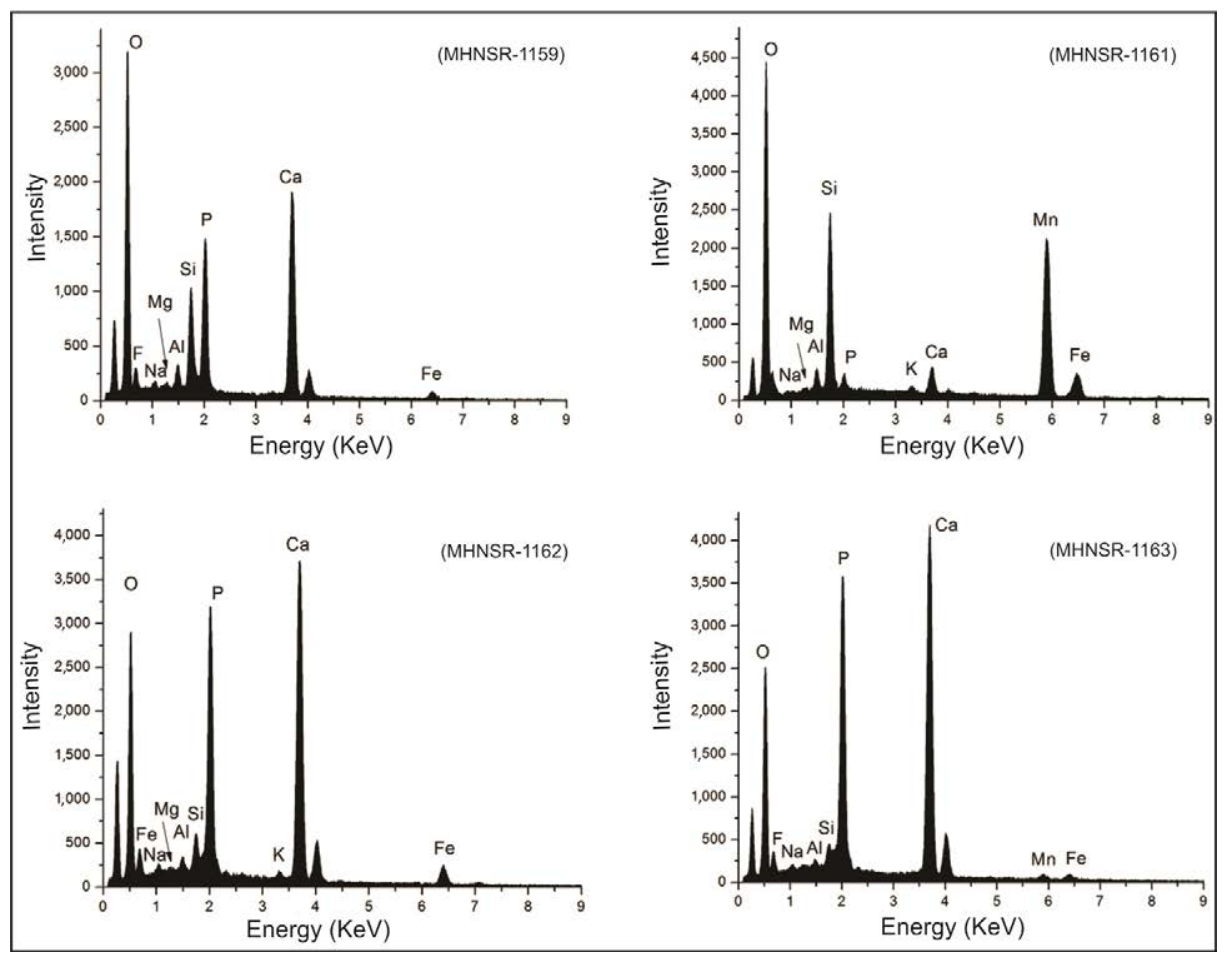

FIG. 5. SEM-EDX results. X-ray spectra of samples (MHNSR.Pv.1159; MHNSR.Pv.1161; MHNSR.Pv.1162 and MHNSR.Pv.1163). Note that graphics (MHNSR.Pv.1159 and MHNSR.Pv.1163) show the presence of fluorine peak at $0.67 \mathrm{keV}$.
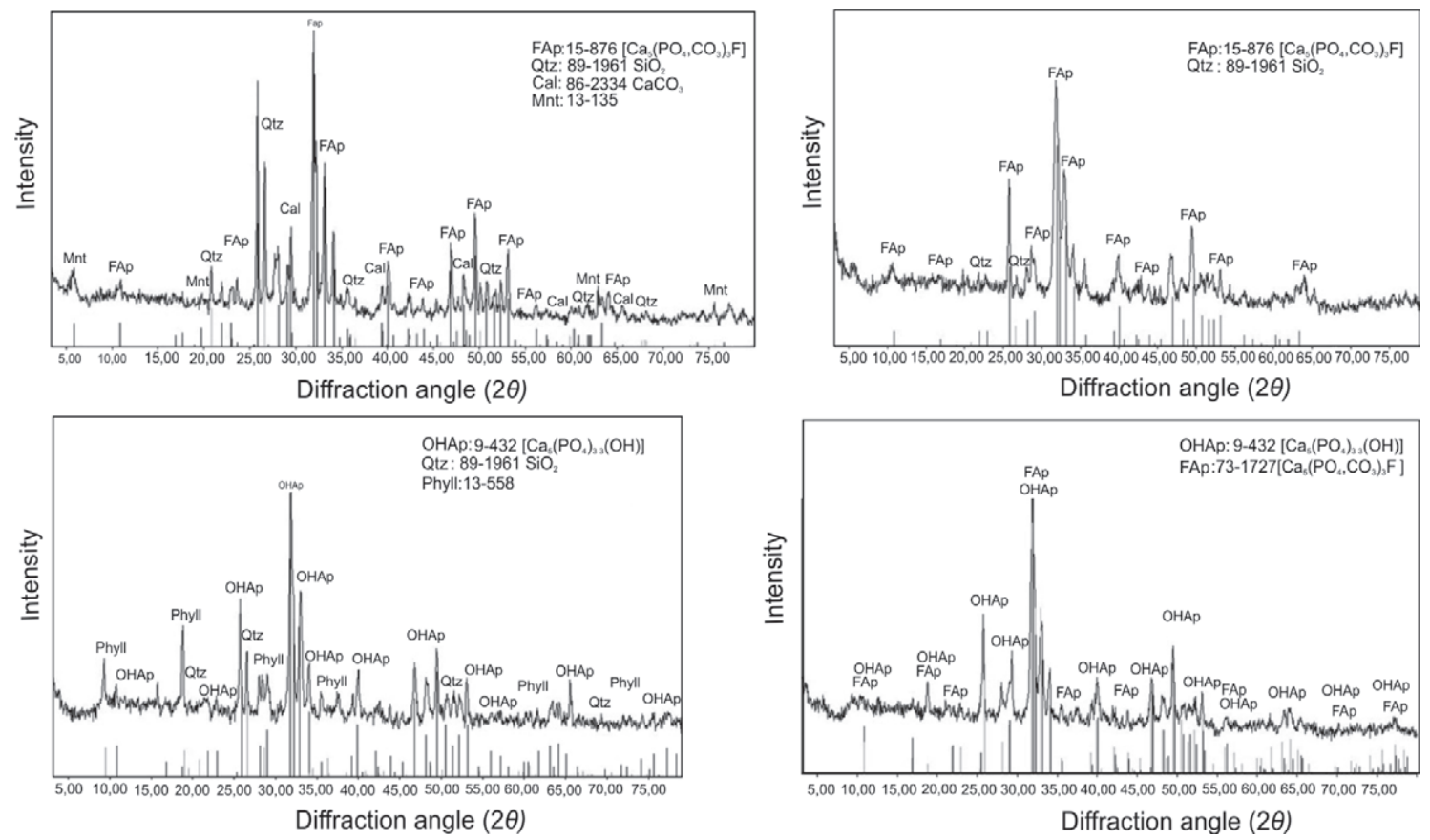

FIG. 6. X-ray diffraction data of therapsid bones (MHNSR.Pv.1159; MHNSR.Pv.1160; MHNSR.Pv.1162 and MHNSR.Pv.1163). 
medullary areas show vascular canals, fractures and cancellous spaces infilled in two permineralization events: (1) an initial iron oxides coating and then (2) calcite cementation (Fig. 4J).

The appendicular bone section displays a thick cortex surrounding the medullary cavity. The fibrolamellar bone contains primary osteons arranged in a sub-plexiform pattern. LAGs are present in the outer and middle cortical region (Fig. 4K). The cortical and medullary areas (Table 1) show vascular canals and trabeculae mainly filled by iron oxides and calcite. The perimedullary region and bony trabeculae show fracturing and brittle deformation (collapse of the spongy tissue) due to lithostatic pressure (Fig. 4K, L). Diagenetic events include: (1) an initial coating of iron oxides in vascular canals and fractures (Fig. 4K) followed by (2) a drusy calcite cementation in vascular canals and cancellous spaces (Fig. 4L) and finally (3) an infiltration of iron oxides imposed onto the medullary tissue (Fig. 4L). This last event may be a result of late diagenetic oxidization of iron minerals (Previtera et al., 2013).

EDX spectra analysis of the following elements: $\mathrm{O}, \mathrm{Na}, \mathrm{Mg}, \mathrm{Al}, \mathrm{Si}, \mathrm{P}, \mathrm{K}, \mathrm{Ca}$, and $\mathrm{Fe}$ is summarized in figure 5 and Table 2. XRD show phosphorus, but not fluorine, so that the presence of apatite corresponds to hydroxyapatite. A small coincident signal is with quartz and with the phyllosilicates group are observed (Fig. 6).

\subsection{MHNSR.Pv.1163, Dicynodont indet.}

These samples consist of a rib and an unidentified appendicular bone of dicynodont found in a floodplain facies. Both elements show similarity in the fibrolamellar bone with primary osteons, some LAGs on the peripheral side, and cancellous bone tissue in the medullary region (Fig. 4M-O).

In these fossil remains it is observed similar diagenetic characteristics (Table 1). Cortical tissues contain primary and secondary osteons filled in three sequential permineralization events: (1) an initial rim of iron oxides (Fig. 4M-O) followed by (2) growth of calcite in vascular canals (Fig. 4M) and then (3) an infiltration of iron oxides in longitudinal fractures of the cortical wall (Fig. 4M, O). In contrast, the medullary cavities show endosteal trabeculae and cancellous spaces with a first iron oxides coating and an infilling geopetal carbonate, with the following diagenetic sequence: (1) an initial deposition of a rim of carbonate-cemented silty sediment followed by (2) a growth of fibrous calcite in vascular canals and finally (3) an event of blocky calcite infilling the center of endosteal trabeculae and cancellous spaces (Fig. 4N).

The substitution of hydroxyapatite by francolite is evidenced by EDX spectra demostrating the presence of fluorine indicated by the peak at $0.67 \mathrm{keV}$ (Fig. 5). XRD analysis shows mainly the presence of apatite considering the following elemental chemical composition: O, F, Na, Al, Si, P, Ca, Mn, and $\mathrm{Fe}$ (Table 2). The presence of fluorine suggests fluorapatite (Fig. 6).

\section{Discussion}

Histological examination of cynodont and dicynodont remains reveals differences in the bone microstructure and growth patterns. These therapsids show a preponderance of well-vascularized fibrolamellar tissue; a variable incidence of growth marks and growth patterns involving an initial rapid growth, which may be interrupted or sustained (Amprino, 1947; de Ricqlès et al., 1991; Chinsamy, 1997). The predominance of fibrolamellar bone indicates that these animals grew quickly but the presence of LAGs indicate periodic arrests in growth. Starck and Chinsamy (2002) have suggested that LAGs are an expression of a high degree of developmental plasticity that is the ability to respond to changes in the environment by evoking different developmental regimes (Smith-Gill, 1983). These interruptions represent changes in the rate of deposition and were probably temperature induced (Ray et al., 2004). The growth marks serve in the identification of the stratification produced by cyclical growth, and also confirm that the bones correspond to adult individuals (Chinsamy-Turan, 2005).

The development of LAGs mentioned in this study as an environmental response to unfavourable periods could be attributed both to the latest Choiyoi volcanic activity and the relatively humid climatic conditions during the deposition of Puesto Viejo Group (Spalletti et al., 2003; Ottone et al., 2014). This instability of the landscape is evident also by the impoverishment of the paleoflora, as has also been proposed for other Triassic successions controlled by volcanic processes (Domnanovich and Marsicano, 2006). The Puesto Viejo therapsids show 
similar histological features to those observed in South Africa Beaufort Group assemblages (Ray et $a l ., 2004)$ and also in Exaeretodon frenguellii from the Ischigualasto Formation, Argentina (Chinsamy and Abdala, 2008).

The elucidation of diagenetic features in fossil remains from floodplain and crevasse splay provides a deeper understanding on their taphonomic history. After death, the carcasses that survived early postmortem destructive processes were buried in the upper soil zone by crevasse splays or accumulation of sediment in the floodplain (Fig.7). Diagenesis included processes as substitution; deformation; fracturing and permineralization stages of iron oxides (e.g., hematite); iron carbonates (e.g., siderite) and calcite during the burial history. Primary pore spaces inside the studied bones include medullary cavities; erosional cavities, primary and secondary osteons, among others. Mineral infillings consist of surrounding sediment; iron oxides, siderite and calcite, however, the amount of particular type of infilling may vary among the bones. The general sequence begins in surrounding sediment filling large vessels from the cortex to internal cavities and, in the cavities; it forms a thin padding around their surface. Below are described the particular sequences observed in the different burial environments.

The bones buried by the crevasse splay (Fig. 7) suffered a brittle deformation due to lithostatic pressure evidenced by the abundance in radial fractures. Subsequently, bone voids and fractures were filled by iron oxides during early diagenetic stages. Later, calcite was the main authigenic mineral that precipitated in the vascular canals and cancellous spaces. Also, a final thin iron oxides infiltration deposited onto the medullary tissue occurred.

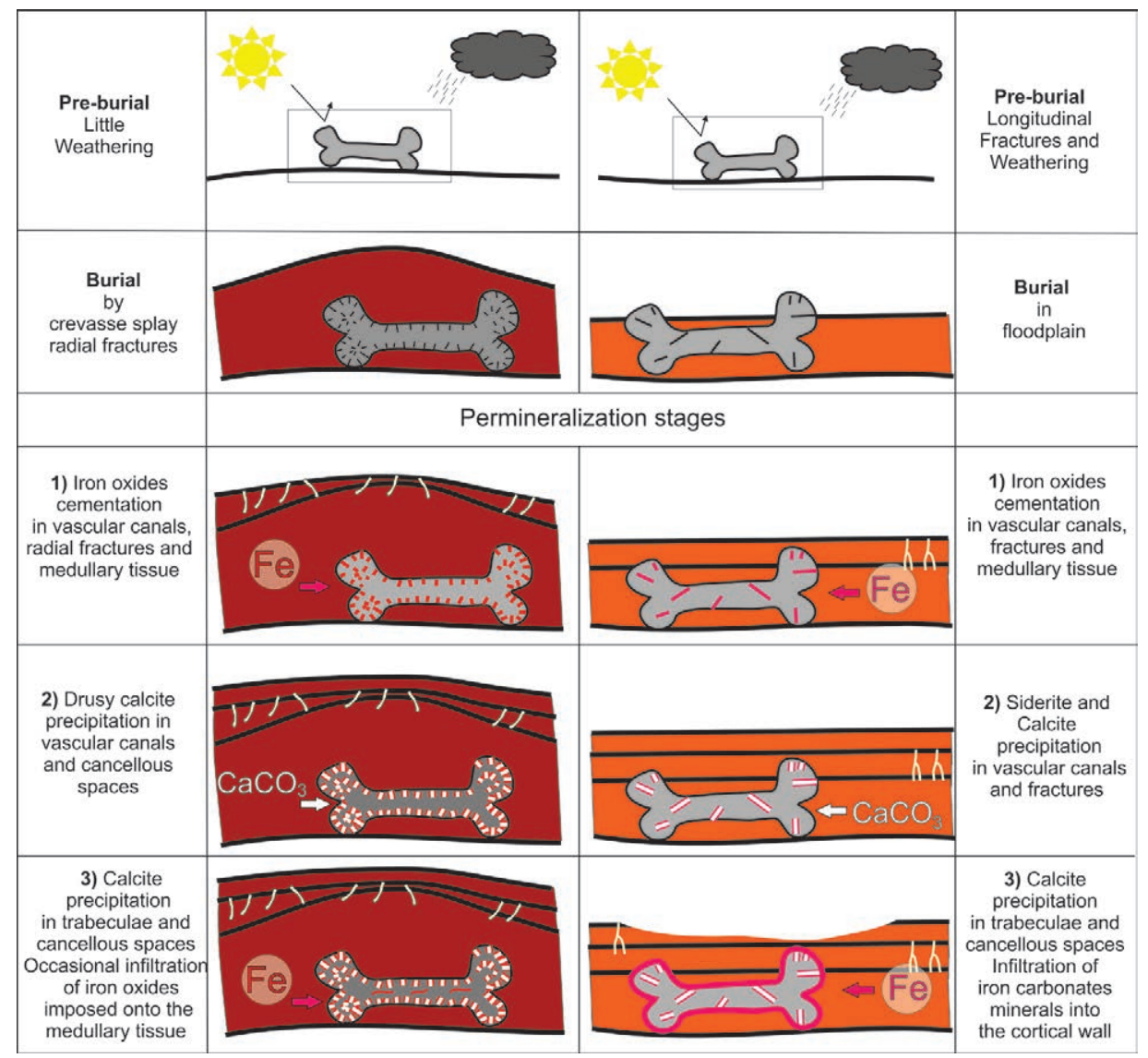

FIG. 7. Schematic diagram summarizing taphonomic processes (weathering and permineralization events) observed in crevasse splay and floodplain facies. 
In contrast, the fossils buried in the floodplain (Fig. 7) display longitudinal fractures associated with weathering and scarce evidence of brittle deformation. During early stages of diagenesis, voids and fractures were cemented by iron oxides, after which took place a siderite and calcite precipitation. Afterwards, the medullary tissue was filled with calcite and also a deposition of iron carbonate minerals into the cortical wall occurred. These remains show a substitution of biogenic apatite by francolite variety in which $\mathrm{PO}_{4}{ }^{3-}$ is substituted by $\mathrm{CO}_{3}{ }^{2-}$ and $\mathrm{OH}^{-}$by F- (McClellan, 1980; Mc-Arthur, 1985; Elorza et al., 1999; Elliott, 2002). The presence of fluoride-bearing apatite in terrestrial fossils is, therefore, an indicator of diagenetic ion exchange through interaction with ground water (Hollocher et al., 2005). Furthermore, the recrystallization of francolite may incorporate carbonate ions from groundwater into bone voids as suggested by Trueman et al., 2004. This type of replacement not observed in the specimens from the crevasse splay. The samples from crevasse splay facies (MHNSR.PV.1161 and MHNSR.PV.1162) lack fluorine contents as fluorapatite.

Bones are preserved only within a restricted field of Eh and $\mathrm{pH}$ conditions that are found in slightly acidic or alkaline soils Retallack (2001). Mineral associations found in the studied bones are as a function of $\mathrm{pH}$ and $\mathrm{Eh}$ conditions of the surrounding environment during diagenesis (Downing and Park, 1998). The iron oxides formation requires oxidizing conditions with $\mathrm{O}_{2}$ as electron acceptor. In continental sediments, iron oxides conditions can persist more than few centimeters below the surface, in the oxidizing zone in soils (Bao et al., 1998). Some of the features of soil and climate that may have contributed to the formation of hematite in RSQ Formation include: iron-rich soil parent materials, alternating wet/dry conditions and fluctuating water tables (Bown and Kraus, 1981; Kraus and Aslan, 1993), episodic flooding or rapid crevasse splay deposition, which limited the time of soil development (Kraus, 1987). Therefore, in the RSQ specimens, the Fe is present probably as hematite in the upper part of the soil. The calcite cemented occurred at the lower levels of the soil, just above water table, as it is described in other researches (Behrensmeyer et al., 1995; Retallack, 1984, 2001; Clarke, 2004). Furthermore, calcite is the main mineral in pore spaces of the RSQ specimens occurring in both spongy and compact bone and it is represented by at least two generations: fibrous calcite cementation and blocky calcite generation. Sedimentary siderite is known as a mineral formed under dysoxic conditions (Lim et al., 2004; Roh et al., 2003). The latter often found in sedimentary deposits with a biological component suggests a biogenic origin under low oxygen and low-Ph conditions, whereby its precipitation is mediated by sulfate and iron reducing bacteria (SánchezRóman et al., 2014; Tobias and Neubauer, 2009; Bodzioch, 2015). In our case, the position of siderite in external part of vascular canals of cynodont rib (MHNSR.Pv.1159) recovered in a floodplain could suggest oxygenation of the bone interior. Similar diagenetic features have been identified in other vertebrate bone remains (Holz and Schultz, 1998; Reichel et al., 2005; González Riga and Astini, 2007; González Riga et al., 2009; Previtera, 2011, 2013; Previtera et al., 2013; Casal et al., 2013, among others).

\section{Conclusions}

In this paper, it has been analyzed therapsid remains from the Upper Triassic in the Río Seco de la Quebrada Formation. Histological examination of these adult individuals reveals a predominance of fibrolamellar bone tissue, suggesting rapid periosteal osteogenesis and overall fast growth. However, the presence of growth rings in fossils indicates that they had an initial fast growth with periodic interruptions followed by a considerable slowing down of growth, which is probably related to environmental stress and a flexible growth strategy.

From a fossil-diagenetic viewpoint, therapsid remains found in floodplain facies and crevasse splay respectively show similar events of permineralization. However, it has been recognized some differences in the types of cements precipitated and the number of diagenetic events occurred during the burial history. EDX, XRD, and petrographic analysis confirm, in three of the cases, the substitution of hydroxyapatite by francolite in the bone microstructure. High fluorine concentrations in samples MHNSR.PV.1159, MHNSR.PV.1160 and MHNSR.PV.1163, not detected in samples MHNSR.PV.1161 and MHNSR.PV.1162, confirm differences between the two sample groups and their depositional environments: floodplain and crevasse splay. These environmental differences 
are the result of burial depth, temperature and geostatic pressure suffered by the fossils in each burial environments. The diagenetic processes observed comprise: substitution; fracturing; brittle deformation and permineralization events. The vascular canals and fractures were mainly filled by iron minerals and carbonates. In both, crevasse splay and floodplain facies, the dominant authigenic mineral is hematite and the main cement of bone voids is calcium carbonate.

This study proposes a functional use of EDX, XRD and petrographic data about diagenetic history to elucidate the relation between paleoenvironments and tetrapod assemblages.

\section{Acknowledgments}

The IANIGLA-CCT-Mendoza provided assistance during laboratory work (electron and petrographic microscopes). EDX and XRD analysis were provided by LABMEM and INTEQUI (UNSL-CONICET), respectively. We gratefully acknowledge J. Wilson (The University of Michigan) for the critical reading of the manuscript and their pertinent comments and anonymous reviewers for their constructive and valuable comments which improved the manuscript. We especially thank C. Marsicano (UBA-CONICET), G. Ottone (UBA-CONICET), M. Bourguet (Ianigla-CONICET) for their support during the fieldwork, and L. Starkman for the critical revision of the English. This research was supported by projects PICT BID 07-373 to M. de la Fuente and PIP CONICET 0209/10 to A.C. Mancuso.

\section{References}

Abdala, F. 1996. Redescripción del cráneo y reconsideración de la validez de Cynognathus minor (Eucynodontia-Cynognathidae) del Triásico Inferior de Mendoza. Ameghiniana 33: 115-126.

Abdala, F.; Ribeiro, A.M. 2010. Distribution and diversity patterns of Triassic cynodonts (Therapsida, Cynodontia) in Gondwana. Palaeogeography, Palaeoclimatology, Palaeoecology 286: 202-217.

Amprino, R. 1947. La structure du tissu osseux envisagée comme l'expression de différences dans la vitesse de l'accroissement. Archives de Biologie 58: 315-330.

Bao, H.; Koch, P.L.; Hepple, R.P. 1998. Hematite and calcite coatings on fossil vertebrates. Journal of Sedimentary Research 68: 727-738.

Barredo, S.; Chemale, F.; Marsicano, C.; Ávila, J.N.; Ottone, E.G.; Ramos, V.A. 2012. Tectono-sequence stratigraphy and $\mathrm{U}-\mathrm{Pb}$ zircon ages of the Rincón
Blanco Depocenter, northern Cuyo Rift, Argentina. Gondwana Research 21: 624-636.

Behrensmeyer, A.K. 1978. Taphonomic and ecologic information from bone weathering. Paleobiology 4: $150-162$.

Behrensmeyer, A.K.; Willis, B.J.; Quade, J. 1995. Floodplains and paleosols of Pakistan Neogene and Wyoming Paleogene deposits: a comparative study. Palaeogeography, Palaeoclimatology, Palaeoecology 115: 37-60.

Blob, R.W. 2001. Evolution of hindlimb posture in nonmammalian therapsids: biomechanical tests of paleontological hypotheses. Palaeobiology 27:14-38.

Bodzioch, A. 2015. Idealized Model of Mineral Infillings in Bones of Fossil Freshwater Animals, on the Example of Late Triassic Metoposaurs from Krasiejów (Poland). Austin Journal of Earth Science 2 (1): 1-6.

Bonaparte, J.F. 1966a. Sobre nuevos terápsidos hallados en el centro de la provincia de Mendoza, Argentina. (Therapsida: Dicynodontia y Cynodontia). Acta Geológica Lilloana 8: 91-100.

Bonaparte, J.F. 1966b. Una nueva "fauna" Triásica de Argentina (Therapsida: Cynodontia-Dicynodontia). Consideraciones filogenéticas y paleobiogeográficas. Ameghiniana 4: 243-296.

Bonaparte, J.F. 1969a. Cynognathus minor n. sp. (Therapsida-Cynodontia). Nueva evidencia de vinculación faunística Afro-Sudamericana a principios del Triásico. Gondwana Stratigraphy 2: 273-281.

Bonaparte, J.F. 1969b. Dos nuevas "faunas" de reptiles triásicos de Argentina. Gondwana Stratigraphy 2: 283-306.

Bonaparte, J.F. 2002. Edad/Reptil Puestoviejense. In Léxico Estratigráfico de la Argentina (Stipanicic, P.N.; Marsicano, C.A.; editors) Triásico. Asociación Geológica, Serie B (Didáctica y Complementaria): 26: 229 p. Buenos Aires.

Botha, J.; Chinsamy, A. 2004. Growth and life habits of the Triassic non-mammalian cynodont Trirachodon inferred from bone histology. Acta Palaeontologica Polonica 49: 619-627.

Bown,T.M.; Kraus, M.J. 1981. Lower Eocene alluvial paleosols (Willwood Formation, northwest Wyoming, U.S.A.) and their significance for paleoecology, paleoclimatology, and basin analysis. Palaeogeography, Palaeoclimatology, Palaeoecology 34: 1-30.

Burley, S.; Kantorowicz, J.Y.; Waugh, B. 1985. Clastic diagenesis. In Sedimentology recent developments and applied aspects (Brenchley, P.; Williams, B.; editors). Blackwell: 189-226. Oxford. 
Casal, G.A.; Martínez, R.D.; Ibiricu, L.M.; González Riga, B.; Foix, N. 2013. Tafonomía del dinosaurio terópodo Aniksosaurus darwini, Formación Bajo Barreal, Cretácico Tardío de Patagonia (Argentina). Ameghiniana 50: 571-592.

Chinsamy, A. 1997. Assessing the biology of the fossil vertebrates through bone histology. Palaeontologia Africana 33: 29-35.

Chinsamy-Turan, A. 2005. The microstructure of dinosaur bone. The Johns Hopkins University Press: 194 p. Baltimore and London.

Chinsamy, A.; Abdala, F. 2008. Palaeobiological implications of the bone microstructure of South American traversodontids (Therapsida: Cynodontia). South African Journal of Science 104: 225-230.

Chinsamy, A.; Raath, M.A.1992. Preparation of fossil bone for histological examination. Palaeontologia Africana 29: 39-44.

Clarke, J.B. 2004. A mineralogical method to determinate cyclicity in the taphonomic and diagenetic history of fossilized bones. Lethaia 37: 281-284.

Colombi, C.E.; Rogers, R.R.; Alcober, R.A. 2013.Vertebrate Taphonomy of the Ischigualasto Formation. Journal of Vertebrate Paleontology 32 (6): 31-50.

Crompton, A.W.1995. Masticatory function in nonmammalian therapsids. In Functional Morphology in Vertebrate Paleontology (Thomason, J.; editor). Cambridge University Press: 55-75. New York.

Curry, K.A. 1999. Ontogenetic histology of Apatosaurus (Dinosauria: Sauropoda): new insights on growth rates and longevity. Journal of Vertebrate Paleontology 19: 654-665.

de Ricqlès, A.; Meunier, F.J.; Castanet, J.; FrancilonVieillot, H.1991. In Comparative microstructure of bone; Bone Matrix and Bone Specific Products. CRC Press Inc., Boca Raton (Hall, B.K.; editor). Bone 3: 1-77.

Domnanovich, N.S.; Marsicano, C.A. 2006. Tetrapod footprints from the Triassic of Patagonia: reappraisal of the evidence. Ameghiniana 43: 55-70.

Domnanovich, N.S.; Marsicano, C.A. 2007. A new shansiodontidae (Therapsida, Dicynodontia) from the Lower Triassic Puesto Viejo Formation (Mendoza, Argentina). Ameghiniana 44: R15-R16.

Domnanovich, N.S.; Marsicano, C.A. 2012. The Triassic dicynodont Vinceria (Therapsida, Anomodontia) from Argentina and a discussion on basal Kannemeyeriiformes. Geobios 45: 173-186.

Downing, K.F.; Park, L.E. 1998. Geochemistry and early diagenesis of mammal-bearing concretions from the
Sucker Creek Formation (Miocene) of southeastern Oregon. Palaios 13: 14-27.

Elorza, J.; Astibia, H; Murelaga, X.; Pereda-Suberbiola, X. 1999. Francolite as a diagenetic mineral in dinosaur and other Upper Cretaceous reptile bones (Laño, Iberian Peninsula): microstructural, petrological and geochemical features. Cretaceous Research 20: 169-187.

Elliott, J.C. 2002. Calcium phosphate biominerals. In Phosphates-Geochemical, Geobiological, and Materials Importance (Kohn, M.J.; Rakovan, J.; Huges, J.M.; editors). Mineralogical Society of America, Reviews in Mineralogy 48: 427-453.

Fernández López, S.R.; Fernández Jalvo, Y. 2002. The limit between biostratinomy and fossildiagenesis. In Current Topics on Taphonomy and Fossilization (De Renzi, M.; Pardo Alonso, M.V.; Belinchón, M.; Peñalver, E; Montoya, P.; Márquez-Aliaga, A.; editors). Ajuntament of Valencia: 27-37. España.

Freytet, P.; Plaziat, J.C. 1982. Continental carbonate sedimentation and pedogenesis e Late Cretaceous and Early Tertiary of Southern France. In Contributions to Sedimentology (Purser, B.H.; editor). SpringerVerlag 12: p. 217.

Gallego, O.F.; Zavattieri, A.M.; Gnaedinger, S.C.; Ballent, S.; De la Fuente, M.; Lara, M.B.; Vaz Tassi, L.; Monferran, M.D. 2009. Nuevos hallazgos paleontológicos en la Formación Quebrada de los Fósiles (Grupo Puesto Viejo), en el límite Pérmico-Triásico de la Argentina. In Reunión Anual de Comunicaciones de la Asociación Paleontológica Argentina, Libro de Resúmenes: p. 45. Buenos Aires.

García, R.A.; Salgado, L.; Coria, R.A.; Chiappe, L.M. 2010. Osteología embrionaria de saurópodos titanosaurios de Neuquén (Argentina): aspectos ontogenéticos y evolutivos. Ameghiniana 47 (4): 409-430.

González Díaz, E. 1972. Descripción geológica de la hoja 27d, San Rafael, Provincia de Mendoza. Servicio Nacional Minero Geológico, Boletín 132: 1-127.

González Riga, B.J.; Astini, R. 2007. Preservation of large titanosaur sauropods in overbank fluvial facies: A case study in the Cretaceous of Argentina. Journal of South American Earth Sciences 23: 290-303.

González Riga, B.J.; Previtera, E.; Pirrone, C.A. 2009. Malarguesaurus florenciae gen. et sp. nov., a new titanosauriform (Dinosauria, Sauropoda) from the Upper Cretaceous of Mendoza, Argentina. Cretaceous Research 30: 135-148.

Holz, M.; Schultz, C.L. 1998. Taphonomy of the south Brazilian triassic herpetofauna: fossilization mode 
and implications for morphological studies. Lethaia 31: 1-12.

Hollocher, K.T.; Alcober, R.A.; Colombi, C.E.; Hollocher, T.C. 2005. Carnivore Coprolites from the Upper Triassic Ischigualasto Formation, Argentina: Chemistry, Mineralogy, and Evidence for Rapid Initial Mineralization. Palaios 20: 51-63.

Kay, S.M.; Ramos, V.A.; Mpodozis, C.; Sruoga, P. 1989. Late Paleozoic to Jurassic silicic magmatism at the Gondwana margin: analogy to middle Proterozoic in North America? Geology 17: 324-328.

Kemp, T.S. 1982. Mammal-like reptiles and the origin of mammals. Academic Press: 363 p. New York.

King, G.M.1988. Anomodontia. In Encyclopedia of Paleoherpetology (Wellnhofer, P.; editor). GustavFischer Verlag, Stuttgart: 17 C: 1-174. New York.

Kitching, J.W.1995. Biostratigraphy of the Cynognathus Assemblages Zone. South African Committe for Stratigraphy and Biostratigraphy Series 1: 40-45.

Kleiman, L.E.; Japas, M.S. 2009. The Choiyoi province at $34^{\circ}-36^{\circ} \mathrm{S}$ (San Rafael, Mendoza, Argentina): Implications for the Late Palaeozoic evolution of the southwestern margin of Gondwana. Tectonophysics 473: 283-299.

Kleiman, L.E.; Salvarredi, J.A. 2001. Petrología, geoquímica e implicancias tectónicas del volcanismo triásico (Formación Puesto Viejo), Bloque de San Rafael, Mendoza. Revista de la Asociación Geológica Argentina 56: 559-570.

Kokogian, D.A.; Fernández Seveso, F.; Mosquera, A. 1993. Las secuencias sedimentarias triásicas. In Geología y Recursos Naturales de Mendoza, Congreso Geológico Argentino No. 12 y Congreso de Exploración de Hidrocarburos No. 2 (Ramos, V.A.; editor), Relatorio: 65-78. Mendoza.

Kokogian, D.A.; Spalletti, L.A.; Morel, E.M.; Artabe, A.E.; Martínez, R.N.; Alcober, O.A., Milana; J.P., Zavattieri, A.M.; Papú, O.H.1999. Los depósitos continentales triásicos. In Geología Argentina (Caminos, R.; editor). Servicio Geológico Minero Argentino, Anales 29: 377-398.

Kokogian, D.A.; Spalletti, L.A.; Morel, E.M.; Artabe, A.E.; Martínez, R.N.; Alcober, O.A.; Milana, J.P.; Zavattieri, A.M. 2001. Estratigrafía del Triásico Argentino. In El Sistema Triásico en la Argentina (Artabe, A.E.; Morel, E.M.; Zamuner, A.B.; editors). Fundación Museo de la Plata: 23-54. Buenos Aires.

Kraus, M.J.1987. Integration of channel and floodplain suites, II vertical relations of alluvial paleosols. Journal of Sedimentary Petrology 57: 602-612.
Kraus, M.J.; Aslan, A.1993. Eocene hydromorphic paleosols: significance for interpreting ancient floodplain processes. Journal of Sedimentary Petrology 63: 453-463.

Kraus, M.J.; Hasiotis, S.T. 2006. Significance of different modes of rhizolith preservation to interpreting paleoenvironmental and paleohydrologic settings: examples from paleogene paleosols, Bighorn basin, Wyoming, U.S.A. Journal of Sedimentary Research 76: 633-646.

Langer, M.C.; Ribeiro, A.M.; Schultz, C.L.; Ferigolo, J. 2007. The continental tetrapod-bearing Triassic of south Brazil. In The Global Triassic (Lucas, S.G.; Spielmann, J.A.; editors). Museum of History, Science Bulletin 41: 201-218. New Mexico.

Lim, D.I.; Jung, H.S.; Yang, S.Y.; Yoo, H.S. 2004. Sequential growth of early diagenetic freshwater siderites in the Holocene coastal deposits, Korea. Sedimentary Geology 169: 107-120.

López Gamundi, O.; Álvarez, L.; Andreis, R.; Bossi, G.; Espejo, I.; Fernández Seveso, F.; Legarreta, L.; Kokogian, D.; Limarino, O.; Sesarego, H. 1989. Cuencas Intermontanas. In Cuencas Sedimentarias Argentinas (Chebli, G.; Spalletti, L.; editors). Universidad de Tucumán, Instituto Superior de Correlación Geológica, Serie Correlación Geológica 6: 123-167. Tucumán.

LLambías, E.J.; Kleiman, L.E.; Salvarredi, J.A. 1993. Magmatismo gondwánico de Mendoza. In Geología y Recursos Naturales de Mendoza (Ramos, V.A. editor). In Congreso Geológico Argentino, No. 12, Relatorio: 53-64. Buenos Aires.

LLambías, E.J.; Sato, A.M. 1995. El batolito de Colangüil: transición entre orogénesis y anorogénesis. Revista de la Asociación Geológica Argentina 50: 111-131.

Mancuso, A.C.; Gaetano, L.C.; Leardi, J.M.; Abdala, F.; Arcucci, A.B. 2014. The Chañares Formation: a window to a Middle Triassic tetrapod community. Lethaia 47: 244-265.

Martinelli, A.G.; De La Fuente, M.; Abdala, F. 2009. Diademodon tetragonus Seeley, 1984 (Therapsida: Cynodontia) in the Triassic of South America and its biostratigraphic inplications. Journal of Vertebrate Paleontology 29: 852-862.

Marsicano, C.; Irmis, R.; Mancuso, A.C.; Mundill, R.; Chemale, F. 2015. The precise temporal calibration of dinosaur origins. PNAS (Proceedings of the National Academy of Sciences of the United States of America) 113: 509-513.

McArthur, J.M.1985. Francolite geochemistry-compositional controls during formation, diagenesis, metamorphism, 
and weathering. Geochimica et Cosmochimica, Acta 49: 23-35.

McClellan, G.H. 1980. Mineralogy of carbonate fluorapatites. Journal of the Geological Society of London 137: 675-681.

Morel, E.M.; Artabe, A.E. 1994. La "Flora de Pleuromeia" en la Formación Puesto Viejo (Triásico) de la provincia de Mendoza, Argentina. In Congreso Argentino de Paleontología y Bioestratigrafía, No. 6, Libro de Resúmenes: p. 4. Chubut.

Ottone, E.G.; García, G.B. 1991. A Lower Triassic miospore assemblage from the Puesto Viejo formation, Argentina. Review of Palaeobotany and Palynology 68: 217-232.

Ottone, E.G.; Monti, M.; Marsicano, C.A.; De la Fuente, M.S.; Naipauer, M.; Armstrong, R.; Mancuso, A.C. 2014. A new Late Triassic age for the Puesto Viejo Group (San Rafael depocenter, Argentina): SHRIMP $\mathrm{U}-\mathrm{Pb}$ zircon dating and biostratigraphic correlations across southern Gondwana. Journal of South American Earth Sciences 56: 186-199.

Previtera, E. 2011. Tafonomía de Dinosaurios Cretácicos de la Cuenca Neuquina sur mendocina, Patagonia Argentina. Ph.D. Thesis (Unpublished), Universidad Nacional de Córdoba: 202 p.

Previtera, E. 2013. Tafonomía de vertebrados del Cretácico Superior de la Formación Loncoche en Calmuco (Mendoza, Argentina): implicancias paleoambientales y paleogeográficas. Ameghiniana 50: 483-492.

Previtera, E.; D’angelo, J.A.; Mancuso, A.C. 2013. Preliminary chemometric study of bone diagenesis in Early Triassic cynodonts from Mendoza, Argentina. Ameghiniana 50: 460-468.

Ramos, V.; Kay, S.M. 1991. Triassic rifting in the Cuyo Basin central Argentina. In Geological Society of America(Harmon, R.S.; Rapela, C.W.; editors). Special Paper: Andean Magmatism and its Tectonic Setting 265: 79 p.

Ray, S. 2000. Endothiodont dicynodonts from the Late Permian Kundaram Formation, India. Palaeontology 43: 375-404.

Ray, S.; Chisamy, A. 2004. Diictodon feliceps (Therapsida, Dicynodontia): bone histology, growth and biomechanics. Journal of Vertebrate Paleontology 24: 180-94.

Ray, S.; Botha, J.; Chinsamy, A. 2004. Bone histology and growth patterns of some nonmammalian therapsids. Journal of Vertebrate Paleontology 24: 634-648.

Reichel, M.; Schultz, C.L.; Pereira, V.P. 2005. Diagenetic pattern of vertebrate fossils from the Traversodontidae Biozone, Santa María Formation (Triassic),
Southern Brazil. Revista Brasileira de Paleontología 8 (3): 173-180.

Reid, R.E.H. 1996. Bone histology of the ClevelandLloyd dinosaurs and of dinosaurs in general. Part I. Introduction: Introduction to bone tissues. Geology Studies 41: 25-71.

Retallack, G.J. 1984. Completeness of the rock and fossil record: some estimates using fossil soils. Paleobiology 10: 59-78.

Retallack, G.J. 2001. Soils of the Past.An introduction to Paleopedology. Blackwell Science: 404 p. Oxford.

Rocha-Campos, A.C.; Basei, M.A.; Nutman, A.P.; Kleiman, L.E.; Varela, R.; LLambias, E.; Canile, F.M.; Da Rosa, O.C.R. 2011. 30 million years of Permian volcanism recorded in the Choiyoi igneous province (W Argentina) and their source for younger ash fall deposits in the Parana Basin: SHRIMP UePb zircon geochronology evidence. Gondwana Research 19: 509-523.

Rogers, R.R.; Arcucci, A.; Abdala, F.; Sereno, P.C.; Forster, C.A.; May, C.L. 2001. Paleoenvironment and Taphonomy of the Chañares Formation tetrapod assemblage (Middle Triassic), northwestern Argentina: spectacular preservation in volcanogenic concretions. Palaios 16: 461-481.

Rogers, R.R.; Fricke, H.C.; Addona,V.; Canavan, R.R.; Dwyer, C.N.; Harwood, C.L.; Koenig, A.E.; Murray, R.; Thole, J.T.; Williams, J. 2010. Using laser ablation-inductively coupled plasma-mass spectrometry (LA-ICP-MS) to explore geochemical taphonomy of vertebrate fossils in the Upper Cretaceous Two Medicine and Judith River formations of Montana. Palaios 25: 183-195.

Roh, Y.; Zhang, C.L.; Vali, H.; Lauf, R.J.; Zhou, J.; Phelps, T.J. 2003. Biogeochemical and environmental factors in Fe biomineralization: magnetite and siderite formation. Caly and Clays Minerals 51: 83-95.

Ruta, M.; Botha-Brink, J.; Mitchell, S.A.; Benton, M.J. 2013. The radiation of cynodonts and the ground plan of mammalian morphological diversity. Proceedings of the Royal Society B 280: 20131865.

Salgado, L.; Coria, R.A.; Chiappe, L.M. 2005. Osteology of the sauropod embryos from the Upper Cretaceous of Patagonia. Acta Palaeontologica Polonica 50: 79-92.

Sánchez-Román, M.; Fernández-Remolar, D.; Amils, R.; Sánchez-Navas, A.; Schmid, T.; Martin-Uriz, P.; Rodríguez, N.; McKenzie, J.A.; Vasconcelos, C. 2014. Microbial mediated formation of Fe-carbonate minerals under extreme acidic conditions. Nature Scientific Reports 4: 4767. doi: 10.1038/step04767. 
Scasso, R.A.; Limarino, C.O. 1997. Petrología y diagénesis de rocas clásticas. Asociación Argentina de Sedimentología, Publicación Especial 1: 259 p.

Schmidt, V.; Mcdonald, P.A. 1979. The role of secondary porosity in the course of sandstone diagenesis. In Aspects of diagenesis (Scholle, P.A.; Schluger, P.R.; editors). Special Publication Society for Sedimentary Geology 26: 175-207. Tulsa.

Sepúlveda, E.G.; Carpio, F.W.; Regairaz, M.C.; Zárate, M.; Zanettini, J.C.M. 2007. Hoja Geológica 3569-II San Rafael. Programa Nacional de Cartas Geológicas de la República Argentina 1:250.000. Servicio Geológico Minero Argentino: 59 p. Buenos Aires.

Smith, R.M.H.1993. Vertebrate Taphonomy of Late Permian floodplain deposits in the southwestern Karoo Basin, South Africa. Palaios 8: 45-67.

Smith, R.M.H.; Swart, R. 2002. Changing fluvial environments and Vertebrate Taphonomy in response to climatic drying in a Mid-Triassic rift valley fill: the Omingonde Formation (Karoo Supergroup) of central Namibia. Palaios 17: 249-267.

Smith-Gill, J.S.1983. Developmental plasticity: developmental conversion versus developmental modulation. American Zoologist 23: 47-55.

Spalletti, L.A. 1994. Evolución de los ambientes fluviales en el Triásico de la Sierra Pintada (Mendoza, Argentina): análisis sobre la influencia de controles intrínsecos y extrínsecos al sistema deposicional. Revista de la Asociación Argentina de Sedimentología 1: 125-142.

Spalletti, L.A.; Artabe, A.E.; Morel, E.M. 2003. Geological factors and evolution of southwestern Gondwana Triassic plants. Gondwana Research 6: 119-134.

Starck, J.M.; Chinsamy, A. 2002. Bone microstructure and developmental plasticity in birds and other dinosaurs. Journal of Morphology 254: 232-246.
Stipanicic, P.N.; Bonaparte, J.F.; Morel, E.M.; Kleiman, L.E. 2002. Formación Puesto Viejo. In Léxico Estratigráfico de la Argentina (Stipanicic, P.N.; Marsicano, C.A.; editors). Triásico, Asociación Geológica, Serie B (Didáctica y Complementaria) 26: 226-229. Buenos Aires.

Stipanicic, P.N.; González Díaz, E.F.; Zavattieri, A.M. 2007. Grupo Puesto Viejo nom. transl. por Formación Puesto Viejo González Díaz, 1964, 1967: nuevas interpretaciones paleontológicas, estratigráficas y cronológicas. Ameghiniana 44: 759-761.

Strelkov, E.E.; Álvarez, L.A. 1984. Análisis estratigráfico y evolutivo de la cuenca triásica mendocina-sanjuanina. In Congreso Geológico Argentino No. 9, Actas: 115130. San Carlos de Bariloche.

Tobias, C.; Neubauer, S.C. 2009. Salt Marsh Biogeochemistry-An Overview. In Coastal Wetlands an Integrated Approach (Perillo, G.M.E.; Volanski, E.; Cahoon, D.R.; Brinson, M.M.; editors). Elsevier: 445-492.

Trueman, C.N.G.; Behrensmeyer, A.K.; Tuross, N.; Weinerd, S. 2004. Mineralogical and compositional changes in bones exposed on soil surfaces in Amboseli National Park, Kenya: diagenetic mechanisms and the role of sediment pore fluids. Journal of Archaeological Science 31: 721-739.

Uliana, M.A.; Biddle, K. 1988. Mesozoic-Cenozoic paleogeographic and geodynamic evolution of southern South America. Revista Brasileira de Geociências 18: 172-190.

Vaz-Tassi, L.; Monti, M.; Gallego, O.F.; Zavattieri, A.M.; Lara, M.B. 2013. The first Spinocaudatan (Crustacea: Diplostraca) from Permo-Triassic continental sequences of South America and its palaeoecological context. Alcheringa 37: 189-201.

Manuscript received: October 09, 2015; revised/accepted: April 18, 2016; available online: April 19, 2016. 